\title{
プリセット方式を用いた磁気アナログシフトレジスタ†
}

\author{
田所嘉昭・穴山武 \\ 東北大学工学部 仙台市荒巻字青葉 \\ (昭和 46 年 10 月 13 日 受付)
}

\section{The Magnetic Analogue Shift Register Using the Preset Method}

\author{
Yoshiaki Tadokoro and Takeshi Anayama \\ (Faculty of Engineering, Tōhoku University, Sendai) \\ (Received October 13, 1971)
}

This paper describes a method for the construction of the analogue shift register suitable for sampled-data systems. The magnetic cores are capable of, isolating the input circuits from the output circuits, and have high reliability in a wide range of environmental conditions. As explained in this paper, the analogue delay elements which are basic units for the shift register are constructed by these cores.

An analogue delay element consists of one core and one flip-flop circuit. This type of delay element is superior to the push-pull type using two cores, because it circumvents the problem of core matching. The input signal is divided into its polarity and absolute value. They are shifted by the binary shift register using flip-flop circuits and by the delay elements using cores, respectively. The errors occurred in the core are compensated by the preset method in which the adaptive value is written-in to the core before the write-in of the signal, and its value can be adjusted for the compensation of errors in every delay element. This method can reduce the number of the cores to half and simplify the adjustment of the readout and write-in characteristics of the delay elements as compared with the push-pull method. As a result, this delay element is simple in construction and has an accuracy of $0.025 \%$.

The difference analyzer is constructed as an application of this shift register. It is made clear that this device is suitable for the study of sampled-data systems.

\footnotetext{
1. ま え がき

アナログシフトレジスタはアナログ遅延素子から構 成され，アナログ信号を順次バケツリレー式に送る機 能を有している。このアナログシフトレジスタは制御 拉よびデータ処理の多重化にともない, サンプリング 的な使用方法が盛んになりつつある現在, 無駄時間シ ミュレータ, 遅延線シンセサイザ (DLS), 相関器な ぞの構成など多くの分野で必要とされ, 重要な位置を しめるものと思われる. 従来この基礎となる遅延素子 として, コンデンサや磁心を利用したものが主に報告

$\dagger$ 第 10 回計測自動制御学会学術講演会で発表 (昭 46.8)
}

されている1) 5).

特に磁心を利用した遅延素子は一般に長時間の遅延 に適し，耐環境性にすぐれ，入出力端子の相互絶縁が 可能であるなどの特徵を有している. しかし，この遅 延素子の精度を向上させるには, 磁心の磁化特性が理 想的でないために生ずる䛊差をなんらかの方法で取り 除くことが必要である. 従来 2 個の磁心を用いたプッ シュプル接続による方式が種々, 報告されている3) 5)。 しかし，この方式の精度は磁心の整合度によって決定 されるので, 使用磁心の整合が実用上, 大きな問題と なる、したがって，この方式の場合は遅延素子の特性 の調整が困難であるといら久点を有している. 
そこで, 単一稵心より遅延素子を構成することがで き,さらに磁心に起因する誤差が簡単な方法で補償さ れるなら, 磁心の特徵をいかした精度のよい遅延素子 が容易に実現されることとなり, 計測および制御など の分野に寄与するところが大であると考光られる.

本研究は，このような観点の下に行なわ机たもので， 従来プッシュプル接続で除いていた磁心に起因する誤 差を以下に述べるプリセット方式により取り除いた。 この方式は信号を磁心に書き込む前磁束レベルをあ る基準点借設定しておくプリセットとよぶ動作を行な い，この制御可能なプリセット量を調整することに゙よ り磁心に起因する誤差を容易に補償する方式である. さらに磁心の磁束量を有効に使用し, 応用の際の周辺 回路を簡単にする目的で，信号の極性と絶対值を分離 してシフトする方式もあわせて検討した。 その結果こ の方式は磁心の整合を考慮する必要がなく,プッシュ プル方式に比べて磁心の数を半分にすることができた。 また，遅延素子の構成，特性の調整が容易になるとと もに $0.025 \%$ 程度の精度が得られることが確かめら れた.

本論文では初めに磁心を利用した遅延素子の基礎的 考察を行ない，ついで信号を極性と絶対值に分離した プリセット方式磁気アナログシフトレジスタについて 述べる. 最後に，このシフトレジスタの一応用例とし て離散系の研究に有用な羑分解析器の構成法と実験結 果を示す。

\section{2. 磁気アナログ遅延素子の基礎的考察}

磁気アナログ遅延素子の原理を Fig. 1 亿示す. 巻

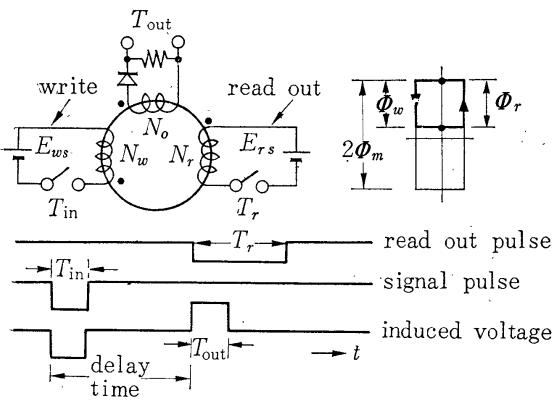

Fig. 1 Principle of analogue delay element using magnetic core

㻁数 $N$ の巻線に高さ $E$, 幅 $T$ の電圧パルスを印加する と, 磁束量の変化 $\Phi_{T}$ は(1)式であらわされる.

$$
\Phi_{T}=\frac{1}{N} \int_{0}^{T} E \cdot d t=\frac{1}{N} \cdot E \cdot T
$$

この式において巻回数 $N$ と電压 $E$ 一定とすると，パ ルス幅 $T$ が磁束量 $\Phi_{T}$ に変換されて記憶されること
になる、このように on-off の2值信号ともみなせる

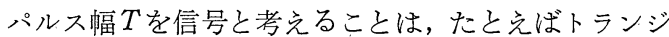
スタスイッチなどを制御することが非常に容易であり 応用上のぞましいものと思わ秃る。いま，理想的な角 形ヒステリシス磁心を用い, 書き込み, 読み出し回路 に抵抗が存在しないものとし，正の飽和レベルを基準 にして遅延素子の動作を考光る. 初如書き达み回路 を入力信号 $T_{\text {in }}$ で導通させ， $T_{\text {in }}$ を磁束レベル $\Phi_{w}$ に書き込む.この磁束レベルは外部から磁束变化を起 こすような作用を受けない限り，磁心の記憶特性によ り半永久的に保持される.必要とされる遅延時間を経 た後, 今度は読み出し回路を読み出しパルス $T_{r}$ で導 通させ，磁束レベルを正の飽和值に復帰させる．正の 飽和レベルに達するまでの磁束量を $\Phi_{r}$ ，そのときの 誘起電圧のパルス幅を $T_{\text {out }}$ (出力パルス) とすると (1)式から (2) 式が導びかれ $N_{w}=N_{r}, E_{w s}=E_{r s}$ と すると(3)式となる.

$$
\frac{1}{N_{w}} E_{w s} \cdot T_{\mathrm{in}}=\frac{1}{N_{r}} E_{r s} \cdot T_{\text {out }} \quad\left(\Phi_{w}=\Phi_{r}\right)
$$

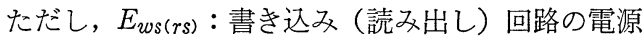
電圧, $N_{w(r)}$ : 書き込久（読久出し）巻線の巻回数.

$$
\left.T_{\text {in }}=T_{\text {out }} \quad \text { (if } N_{w}=N_{r}, E_{w s}=E_{r s}\right)
$$

上式の上うに入力信号 $T_{\text {in }}$ と出力信号 $T_{\text {out }}$ は, 原 理的に一致することになる。

Fig. 1 では角形ヒステリシス磁心を理想化して遅 延素子の原理を示した。しかし実際の磁心に执いては, Fig. 2 亿示寸ようなヒステリシススループを描く，同 図から磁心を利用した遅延素子の誤差の原因として以 下の事項が問題になるものといえる.

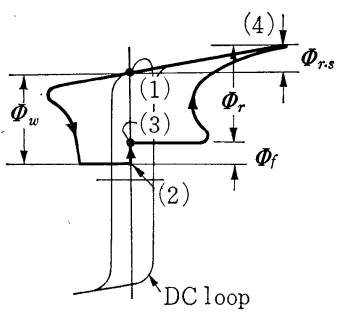

Fig. 2 Hysteresis loop in a actual core

（1）もぞり磁束量 $\left(\Phi_{f}\right)$ : 書き込反終了後, 起磁 力の消滅とともに磁束量が逆にじゃっかんもどり, 信 号を減少させる $((2) \rightarrow(3))$. この磁束のもどり量をも ぞり磁束量とよぶことにする。この量は磁心の特性特 よび回路条件で異なるとともに，磁束レベルや書き込 久速度 $\left(d \Phi / d t \simeq E_{w s} / N_{w}\right)$ などによっても複雑に变化 することが知られている6) 9)，本実験に使用した磁心 のもどり磁束量の一例を Fig. 3 に示す.

（2）励磁電流の磁束レベルによる非線形な変 


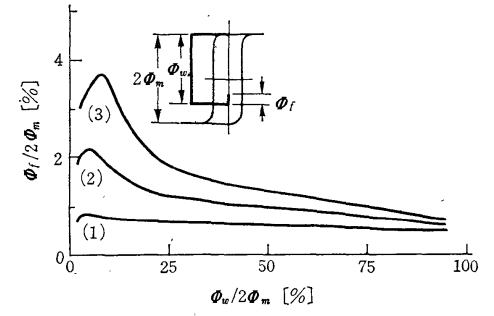

(1) $d \Phi / d t=27 \mathrm{mV} / \mathrm{T} \quad$ (2) $d \Phi / d t=115 \mathrm{mV} / \mathrm{T}$

(3) $d \Phi / d t=220 \mathrm{mV} / \mathrm{T}$

core : $50 \%$ Fe-Ni Permalloy

$2 \Phi_{m} \fallingdotseq 110 \mu \mathrm{Wb}(0.025 \times 10 \times 25 \times 35 \mathrm{~mm})$

Fig. 3 Relation between amount of flyback flux and flux level

化*：磁心の励磁電流が磁束レベルの值に対して非線 形な変化をすれば，書き込み，読み出し回路の抵抗に よる電圧降下の違いのため, 磁心汭る電圧も同様 に非線形な変化をし，定電圧による書き込久，読久出 しの線形性が満足されなくなる。

（3）残留磁束量 $\left(\Phi_{r \cdot s}\right)$ : 角形比が完全に1でな いために生ずる磁束量で信号を增加させる $((1) \rightarrow(4))$. 以上の誤差の原因を考慮し，遅延素子の入出力特性を (4)式示す.

$$
\begin{aligned}
& \frac{1}{N_{w}}\left(E_{w s}-\bar{I}_{w} r_{w}-e_{w 0}\right) \cdot T_{\mathrm{in}}+\Phi_{r \cdot s} \\
& \quad=\frac{1}{N_{r}}\left(E_{r s}-\bar{I}_{r} r_{r}-e_{r 0}\right) \cdot T_{\mathrm{out}}+\Phi_{f}
\end{aligned}
$$

ただし， $\bar{I}_{w(r)}$ : 書き込み（読及出し）時の平均励 磁電流, $r_{w(r)}, e_{w_{0}\left(r_{0}\right)}$ : 書き込反 (読及出し) 回路 の電圧電流特性を線形近似したときの抵抗と不感帯 電圧.

さらに $N_{w}=N_{r}=N, E_{w s}=E_{r s}=E_{s}$ とし, 2 次以上 の微小項を消略し， $T_{\text {out }}$ と $T_{\text {in }}$ の関係を整理すると (5)式となる.

$$
\begin{aligned}
T_{\text {out }}= & T_{\text {in }}-\frac{1}{E_{s}}\left\{\left(\bar{I}_{w} r_{w}-\bar{I}_{r} r_{r}\right)+\left(e_{w 0}-e_{s 0}\right)\right\} T_{\text {in }} \\
& +\frac{N}{E_{s}}\left(\Phi_{r \cdot s}-\Phi_{f}\right)\left(1+\frac{\bar{I}_{r} r_{r}+e_{r 0}}{E_{s}}\right)
\end{aligned}
$$

第2.項以下が誤差になる.プッシュプル方式は, これ らの誤差を 2 個の磁心で互いに打ち消し合うように構 成されている。しかし， $\bar{I}_{w(r)}, \Phi_{f}$ など非線形な変化 をするものに対してはプッシュプル接続の効果も少な い. 特にもどり磁束量 $\Phi_{f}$ は誤差に大きな影響を打 よぼす。これらに対する一般的な対策としては, $\bar{I}_{w(r)}$ については抵抗の小さい巻線を適当代多く巻き $\bar{I}_{w(r)}$

* 動的磁化過程においては渦電流などにより必要なエネ ルギが増大し，ヒステリシスの幅が值流ヒステリシス より増大する 変化する ${ }^{11)}$.
の值を小さくするとともに，書き込み，読み出し回路の 抵抗をできるだけ小さくすることである． Ф ては $\Phi_{f}$ の少ない磁心 ${ }^{6)}$,7)を選び, Fig.?3'からわかるよ うに $\Phi_{f}$ の小さい低速度書き込及で使用することが有 効である。磁心をアナログ遅延素子として使用する場 合は以上のことを考慮した上で使うことが必要である。

アナログシフトレジスタは，上述の遅延素子が直列 に数段接続されて構成される. その場合, サンプリン グ周期 $T_{s}$ の整数倍遅れた信号を同時に取り出せるこ とが応用上のぞむしいが，1個の遅延素子では同時に 書き达みと読み出しの動作を行なうことができない． そこで Fig. 4 に示すよう遅延素子 2 個で単位遅延 素子を構成することにする. 本構成法はサンプリング 時に拉いて書き込みを前段の遅延素子に，読及出しを 後段の遅延素子にうけもたせることにより，サンプリ ング周期 $T_{s}$ の整数倍遅れた信号を同時にとりだすこ。 とができる。

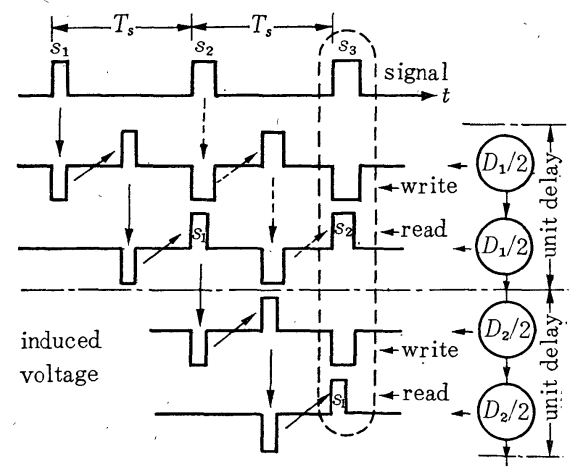

Fig. 4 Unit delay element for shift register

\section{3. プリセット方式磁気アナログシフ トレジスタ}

磁心を利用した高精度の遅延素子を作る困難さの一。 因は，信号の極性といらディジタル量と絶対值といら アナログ量を一緒に取り扱うことに起因していると考 光られる，そこでここでは，信号を極性と絶対值に分 離し，極性をフリップフロップに絶対值を磁気遅延素 子に受けもたせる方式を考案し、アナログシフトレジ ス文を構成した。

\section{$3 \cdot 1$ プリセット方式}

上記のように，遅延素子は信号の絶対值の夕を扱光 ばよいことになる。それゆ克，原理的に全磁束量 $2 \Phi_{m}$ を使用することができる。

2. で述べた磁心を利用した遅延素子の誤差の原 因 となるもどり磁束量, 残留磁束量などの影響を，Fig. 5 亿示す方法で取り除いた。 まず信号 $T_{\text {in }}$ を書き込 


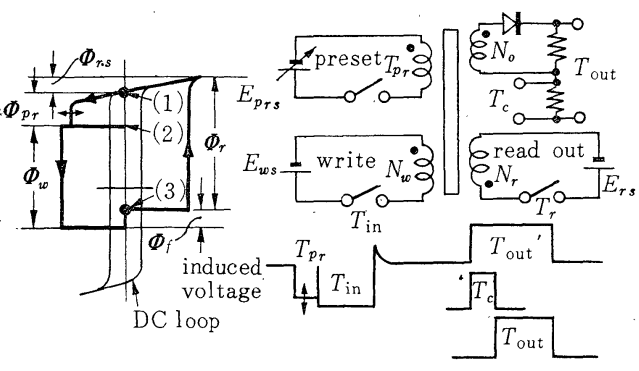

Fig. 5 Analogue delay element using preset method さ前に基準点を(1)より(2)へ移しておく（この動作をプ リセットとよぶ)。その後, 信号 $T_{\text {in }}$ は書き込まれる

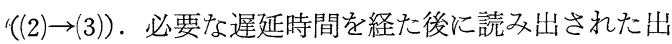
カパルス $T_{\text {out }}{ }^{\prime}$ は, 信号成分以外飞プリセットに相当 する成分を含むので，これを一定な補正パルス $T_{c}$ で 差し引き信号 $T_{\mathrm{in}}$ を取り出す．このプリセットによ って, ヒステリシスの正の飽和付近でのもどり磁束量, 励磁電流の非線形性が著しい範囲を避けるとともに, この制御可能なプリセット量を調整して, るどり磁束 量, 残留磁束量による誤差を取り除くことができる. この方式をプリセット方式とよぶことにする。，この方 式に抒いて注意しなければならないことは, 出力パル ス幅 $T_{\text {out }}{ }^{\prime}$ を常に一定な補正パルス $T_{c}$ で差し引く ため, Fig. 5 と示すようにプリセット後直ちに信号 を書き込むようにして，プリセットによるもどり磁束 を生じさせないことである。なぜなら，プリセット後， ある時間たった後に信号を書き込むことにすると，信 号がないときはプリセットによるもどり磁束の及が発 生し，信号があるときはプリセットによるもどり磁束 ，と信号によるもどり磁束と，もどり磁束が 2 度生ずる ことになり，信号の有無によって，もどり磁束の影響 が異ならてしまうためである。

この方式の入出力特性を求めるために, Fig. 5 の ヒステリシスの関係を式で表わし整理すると（6）式 となる。

$$
\begin{aligned}
T_{\text {out }}{ }^{\prime}= & \frac{N_{r}}{N_{w}} \cdot \frac{\bar{E}_{w}}{\bar{E}_{r}} \cdot T_{\mathrm{in}}+\frac{N_{r}}{N_{p r}} \cdot \frac{\bar{E}_{p r}}{\bar{E}_{r}} \cdot T_{p r} \\
& +\frac{N_{r}}{\bar{E}_{r}}\left(\Phi_{r \cdot s}-\Phi_{f}\right)
\end{aligned}
$$

ただし， $\bar{E}_{w(r, p r)}$ : 書き込み（読み出しプリセッ 卜) 時滋心にかかる平均電圧 $\left(\bar{E}_{w}=E_{w s}-r_{w} \bar{I}_{w}\right.$ 一 $e_{w 0}$ など), $T_{p r}$ :プリセットパルス幅.

補正パルス $T_{c}$ には(6)式で $T_{\mathrm{in}}=0$ と打いた(7) 式で表わされるパルス幅を使う。これょり入出力特性 梳(8)式で表わされる.

$$
T_{c}=\frac{N_{r}}{N_{p r}} \cdot \frac{\bar{E}_{p r}}{\bar{E}_{r}} \cdot T_{p r}+\frac{N_{r}}{\bar{E}_{r}}\left(\Phi_{r \cdot s}-\Phi_{f \cdot p r}\right)
$$

ただし， $\Phi_{f \cdot p r}: T_{\mathrm{in}}=0$ のときのプリセットによる もどり磁束量.

$$
T_{\text {out }}=T_{\text {out }}{ }^{\prime}-T_{c}=\frac{N_{r}}{N_{w}} \cdot \frac{\bar{E}_{w}}{\bar{E}_{r}} \cdot T_{\text {in }}+\frac{N_{r}}{\bar{E}_{r}}\left(\Phi_{f \cdot p r}-\Phi_{f}\right)
$$

信号による $\bar{E}_{w}, \bar{E}_{r}$ の変化を無視し，もどり磁束量 $\Phi_{f}$ が(9)式で表わされるなら（8)式は（10）式となり 利得を 1 亿調整すれば入出力特性は理想的な (12)式と なる。

$$
\begin{gathered}
\Phi_{f}=k_{f} \cdot T_{\mathrm{in}}+\Phi_{f \cdot p r} \quad\left(k_{f} \text { は定数 }\right) \\
T_{\text {out }}=\left(\frac{N_{r}}{N_{w}} \cdot \frac{\bar{E}_{w}}{\bar{E}_{r}}-k_{f} \frac{N_{r}}{\bar{E}_{r}}\right) \cdot T_{\mathrm{in}} \\
\text { 利得 }=\frac{N_{r}}{N_{w}} \cdot \frac{\bar{E}_{w}}{\bar{E}_{r}}-k_{f} \frac{N_{r}}{\bar{E}_{r}}=1 \\
T_{\text {out }}=T_{\mathrm{in}}
\end{gathered}
$$

なお，(9)式を成立させるためには，Fig. 3 から明 らかなよらにプリセットによってもどり磁束量の非線 形性が著しい部分を除くことが必要である。また，低 速度書き込久で使用した活らがその線形性の範囲が増 大寸る。

この特性の調整は以下に述べる方法で行なら。まず 零点の調整は ( 7 )式が成立するようにすればよい。它 こで補正パルス $T_{c}$ は一定として扮き，各磁心によっ て異なる $\Phi_{r . s}, \Phi_{f \cdot p r}$ の影響をプリセット電圧 $\bar{E}_{p r}$ を 調整して補償し，（7）式の右辺が一定值 $T_{c}$ になるよ らにする.この $\bar{E}_{p r}$ による零点の調整は (11) 式から 明らかなように利得には影響を斿よ济さない。いっぽ ら, 利得の調整を零点と独立に行なうには(7)式に影 響を与兄ない $N_{w}$ と $\bar{E}_{w}$ によって行なう。この関係 を Table 1 に示す.

Table 1 Method for adjustment of zero point and gain

\begin{tabular}{c|c}
\hline items & controllable paramenters \\
\hline zero point & $\bar{E}_{p_{r}}$ \\
\hline gain & rough $; N_{w}$, fine $: \bar{E}_{w}$ \\
\hline
\end{tabular}

Fig. 5 では書き込みと読み出しの巻線を別々に示 してある.このように巻線を別にすると 1 つ電源を 書き込み,読又出しの電源として使用でき, (11)式など からもわかるように電源変動によって生ずる利得の変 動を和さえることができる.いっぽう,磁心を利用した 装置を作成するとき，その巻線を単純にしたいという 要求がある.そこで本実験では1つの巻線を書き込み, 読み出し, プリセットの各巻線として共用し, 書き込 み回路と読み出し回路の電源を別とした. しかし前章 で述べたようにシフトレジスタは 2 個の遅延素子でも 


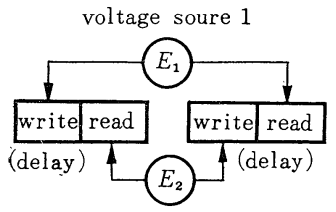

vol tage soure 2
Fig. 6 Voltage source of unit delay element
って単位途延素子が構成される。とれゆえ Fig. 6 に 示すような電源の使い方をすることにより単位遅延素 子としては書き込みと読及出しの電源が共通になり， 電源変動に対する安定性も大きくすることができる。 また，プリセットと補正は，各遅延素子で行なう必要 はなく，前段の遅延素子でプリセットを行ない，後段 の遅延素子で補正を行な光ばよい。この場合,プリセ ットパルス幅 $T_{p r}$ と補正パルス幅 $T_{c}$ とに同じパル ス源を使用することにより，このパルス幅变動による 零点の変動を拈さ光ることができる。

実際の単位遅延素子の回路を Fig. 7 に示す。プリ セット電源は書き込久電源と共通である。プリセット 回路中の可変抵抗 $R_{p r}$ はプリセット電圧 $\bar{E}_{p r}$ を変克 てプリセット量を加減する零点調整用のものである。 また，書き込久回路の巻線 $N_{a d}$ は書き込久巻回数 $N_{w}$ を変える利得調整用のものである. 出力回路にト ランジスタ $T_{r a}$ を入れたのは, むどり磁束による誘 起電圧が次段に書き込ま机るのを防止するためである.

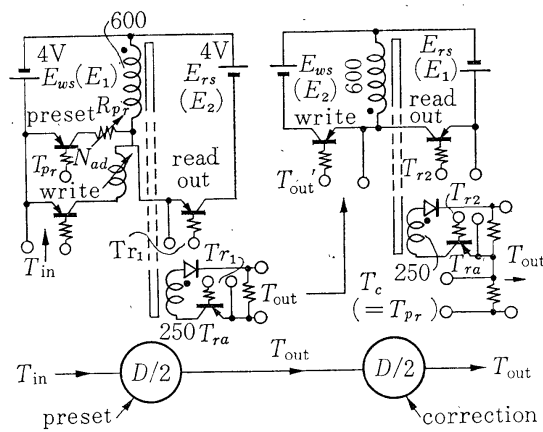

Fig. 7 Circuit of unit analogue delay element

この遅延素子の磁心として Table 2 亿示寸特性の 磁心を使用し，（9)式が注淁成立する Table 3 亿示 す条件のもとに単位遈延素子の入出力特性を測定した 結果を Fig. 8 と示す. 横軸が入力パルス幅 $T_{\text {in }}$ で綎 軸は出力パルス幅 $T_{\text {out }}$ と $T_{\text {in }}$ の差（誤差）を表わ している. 室温に拁ける入出力特性の誤差は同図に示 すように最大入力パルス幅 $12 \mathrm{~ms}$ に対して約 0.025 \%である. 電源電压 $4 \mathrm{~V}$ を 4 \% 変動ざせたときの 特性の誤差は $0.04 \%$ 以下である. 温度に対する安定 性を調べるため磁束レベル $50 \%$ に抒いて，出力パル
Table 2 Property of $50 \% \mathrm{Fe}-\mathrm{Ni}$ Permalloy core*

\begin{tabular}{c|c}
\hline items & values \\
\hline $2 \Phi_{m}$ & $110 \mu \mathrm{Wb}$ \\
\hline$B_{r} / \mathrm{B}(8 \mathrm{AT})$ & $98 \%$ \\
\hline$H_{c}$ & $\begin{array}{l}8.8 \mathrm{AT} / \mathrm{m} \\
(0.11 \mathrm{Oe})\end{array}$ \\
\hline
\end{tabular}

Table 3 Conditions

\begin{tabular}{c|c}
\hline items & conditions \\
\hline $\begin{array}{c}E_{w s} / N_{w}, E_{r s} / N_{r} \\
\text { (switching time) }\end{array}$ & $\begin{array}{c}6.5 \mathrm{mV} / \mathrm{T} \\
(15 \mathrm{~ms})\end{array}$ \\
\hline $\begin{array}{c}\Phi_{p_{r}} / 2 \Phi_{m} \\
\left(T_{p_{r}}\right)\end{array}$ & $\begin{array}{c}10 \% \\
(1.5 \mathrm{~ms})\end{array}$ \\
\hline
\end{tabular}

* spiral core size :

$(0.025 \times 10 \times 25 \times 35) \mathrm{mm}$

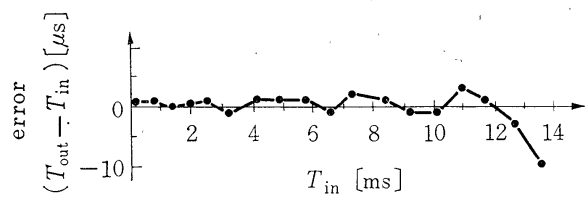

Fig. 8 Errors of input and output characteristic of unit analogue delay element

ス幅の変動を測定した結果, $25^{\circ} \mathrm{C}$ から $50^{\circ} \mathrm{C}$ の範囲 では遅延素子のトランジスタがゲルマニウム拈よびシ リコンの場合も，その変動は認められなかった。それ 以上の温度に対してはゲルマニウムの場合は $50^{\circ} \mathrm{C}$ か ら $60^{\circ} \mathrm{C}$ で $-1.5 \mu \mathrm{s} /{ }^{\circ} \mathrm{C}$ シリコンの場合は $50^{\circ} \mathrm{C}$ か ら $70^{\circ} \mathrm{C} て ゙+0.3 \mu \mathrm{s} /{ }^{\circ} \mathrm{C}$ の変動であった.

\section{2 アナログシフトレジスタの構成}

この節では前節の遅延素子を用い，シフトレジスタ を構成する方法を述べる．この原理を Fig. 9 亿示す，

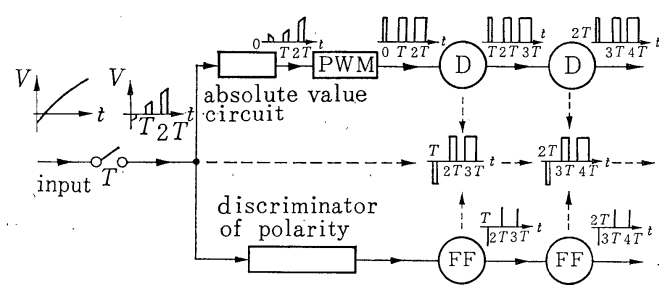

PWM : pulse width modulator $\mathrm{D}:$ delay element FF : flip-flop

Fig. 9 Analogue shift register separating absolute value and polarity

サンプリングされた入力信号の一方は，絶対值回路に 上り絶対値值され, さらにパルス幅変換器 (PWM) によりパルス幅に変換される，そして，このパルス幅 そなった信号の絶対值が前節で述べたプリセット方式 を用いた遅延素子でシフトされていく.いっぽう，入 力信号の極性は極性判別器で判別され, フリップフロ ップからなる 2 進シフトレジスタで順次送られる.以 下，遅延回路を除く他の回路について述べる.

入力信号の絶対值を作るための絶対值回 路は Fig. 10 に示すように, 演算増幅器を用いて構成した ${ }^{12}$. 


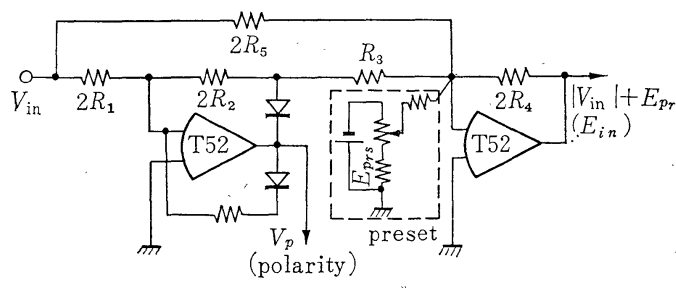

Fig. 10 Circuit for realizing of absolute value

入力電圧 $\pm 10 \mathrm{~V}$ に対して $0.02 \%(2 \mathrm{mV} / 10 \mathrm{~V})$ の精 度を得た. 極性出力 $V_{p}$ も同時に取り出すことができ, 極性判別器の機能もかねとな党る.この電圧 $V_{p}$ をサ ンプリングして 2 進シフトレジスタの初段のセットパ ルスとして使用する.

パルス幅変換器 (PWM) は磁心を用いて Fig. 11

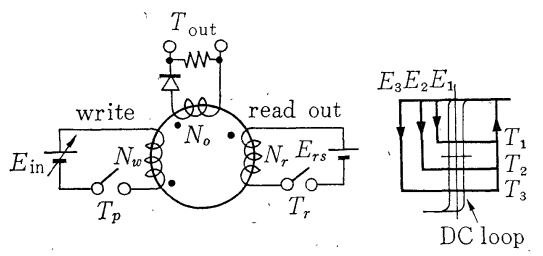

Fig. 11 Principle of pulse width modulator using magnetic core

に示す原理のもとに構成した。この原理は Fig. 1 の 遅延素子の原理とほぼ同様であるが，書き込々回路を 閉じる期間 $T_{p}$ を一定として，書き込久電圧 $E_{\mathrm{in}}$ を 信号としたことが異なる。遅延素子の場合と同様に (13)式が導びかれる.

$$
\begin{aligned}
& T_{\text {out }}=\frac{N_{r}}{N_{w}} \cdot \frac{E_{\text {in }}}{E_{r s}} \cdot T_{p}=k_{p} \cdot E_{\text {in }} \\
& \text { ただし, } k_{p}=\left(N_{r} / N_{w}\right) \cdot\left(1 / E_{r s}\right)
\end{aligned}
$$

すなわち, 入力電圧 $E_{\mathrm{in}}$ がパルス幅変換係数 $k_{p}$ によ り $T_{\text {out }}$ なるパルス幅に変換される.実際の回路を Fig. 12 に示す. 入力インピーダンスを大きくするた め書き込久回路㴔帰還巻線 $N_{w b}$ を設け，これによ って磁束変化速度を制御する。また，読及出し回路は

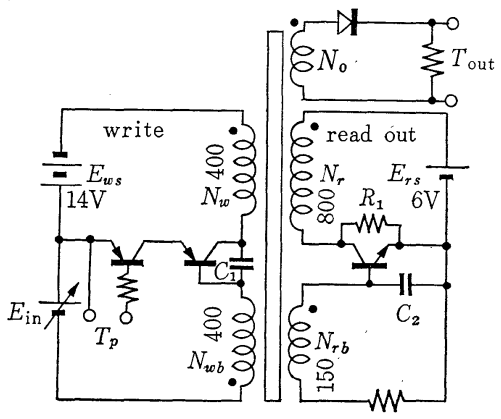

Fig. 12 Circuit of pulse width modulator
正帰還により書き込み終了後, 直ち汇読み出しが行な われる. 入力電圧 $1 \mathrm{~V}$ から $13 \mathrm{~V}$ に対して約 $0.05 \%$ の精度の変換器が兄られた. シフトレジスタを構成す る場合, この PWM は初段の単位遅延素子の前段の 遅延素子の役目もかねる。この PWM の回路にはプ リセット回路を設けてないが，このプリセット量は Fig. 10 亿示した絶対值回路の点線で囲んだ部分より 与えられ，この電圧を調整することにより零点調整が 行なわれる。

極性の方を受けもつ 2 進シフトレジスタは Fig. 13 の原理のもとにトランジスタを用いて構成した ${ }^{13)}$.

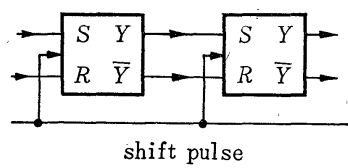

Fig. 13 Binary shift register

\section{$3 \cdot 3$ プッシュプル方式との比較}

この章で述べた方式は，プリセットという動作を入 れたことと，信号を極性と絶対值に分離してシフトす ることが特徵である．このプリセット方式が従来のプ ッシュプル方式に比べ，どのような特徵があるかシフ トレジスタを構成する場合の単位遅延素子に対して比 較してみる.（1）制御可能なプリセット量を調整して， 個々の磁心で異なるもどり磁束量, 残留磁束量による 誤差を補償するようにしたため，プッシュプル方式の 場合のように整合のとれた磁心を選択する必要がなく なるとともに，磁心の数を半分に減らすことができた。 さらに，このプリセットといらバイアスパルスを信号 と独立させたため利得と零点の調整を独立に行なうこ とができ, 遅延素子の特性の調整が容易になった。

（2）信号を極性と絶対值に分離したことにより，ほぼ 全磁束量 $2 \Phi_{m}$ が利用できた. また, パルス幅変換器

Table 4 Comparison between preset method and push-pull method

\begin{tabular}{c|c|c}
\hline items & preset method & push-pull method \\
\hline $\begin{array}{l}\text { unit delay element } \\
\text { (number of semi- } \\
\text { conductor) }\end{array}$ & $\left.\begin{array}{l}\text { two cores, one flip- } \\
\text { transistor : 9 } \\
\text { diode }: 4\end{array}\right)$ & $\left.\begin{array}{c}\text { four cores } \\
\text { transistor : 10 } \\
\text { diode }: 4\end{array}\right)$ \\
\hline $\begin{array}{l}\text { core matching } \\
\text { adjustment of zero } \\
\text { point and gain }\end{array}$ & $\begin{array}{l}\text { independent and } \\
\text { simple }\end{array}$ & $\begin{array}{l}\text { dependent and } \\
\text { difficult }\end{array}$ \\
\hline $\begin{array}{l}\text { amount of infor- } \\
\text { circumfion } \\
\text { circuit }\end{array}$ & $2 \Phi_{m}$ & $\Phi_{m}$ \\
\hline winding & simple & complex \\
\hline attached circuit & $\begin{array}{l}\text { absolute value } \\
\text { circuit }\end{array}$ & complex \\
\hline
\end{tabular}


および応用のさいの乗算回路などの周辺回路を簡単に することができた．以上のことを Table 4 に示す.

\section{4. 一 応用 例}

この章では 3. で述ベたシフトレジスタの一応用例 として, 差分解析器の構成法とその実験結果を述べる。

この差分解析器はサンプル值系など差分方程式で表 わされる物理系の研究に有用であると考えられる. そ の目的としている機能は, 微分方程式で表わされる連 続系の研究に対して, 現在, 使用されているアナログ 計算機（微分解析機）がもつ機能と同様なものである. すなわら手軽に物理系の応答を考察したり, 系をシミ ュレートできることである。

アナログ計算機に打ける演算堌幅器に相当するのが 差分解析器では遅延素子であり, この遅延素子より構 成されるシフトレジスタがこの装置の基礎となると れゆえ, シフトレジスタの精度は差分解析器の精度に 重要な位置をしめる。また，このような装置に执いて は装置の調整が容易でなくてはならない，3. で述べ たシフトレジスタはこれらの条件を満足しており，こ れを基礎にして差分解析器を構成した ${ }^{14) ~ 16)}$. 以下， (14)式で示される定数係数の 2 階の差分方程式につい て, その解析器の構成法と実験結果を示す.

$$
U(t)+a \cdot U(t-1))+b \cdot U(t-2)=R(t)
$$

(14) 式を解くための差分解析器の原理を Fig. 14 に 示す. 遅延素子, 係数乗算器それに加算器の 3 つの要 素より構成される. Fig. 15 は 3. で述べたシフトレ ジスタを使用した具体的な構成図であり, 各要素を点

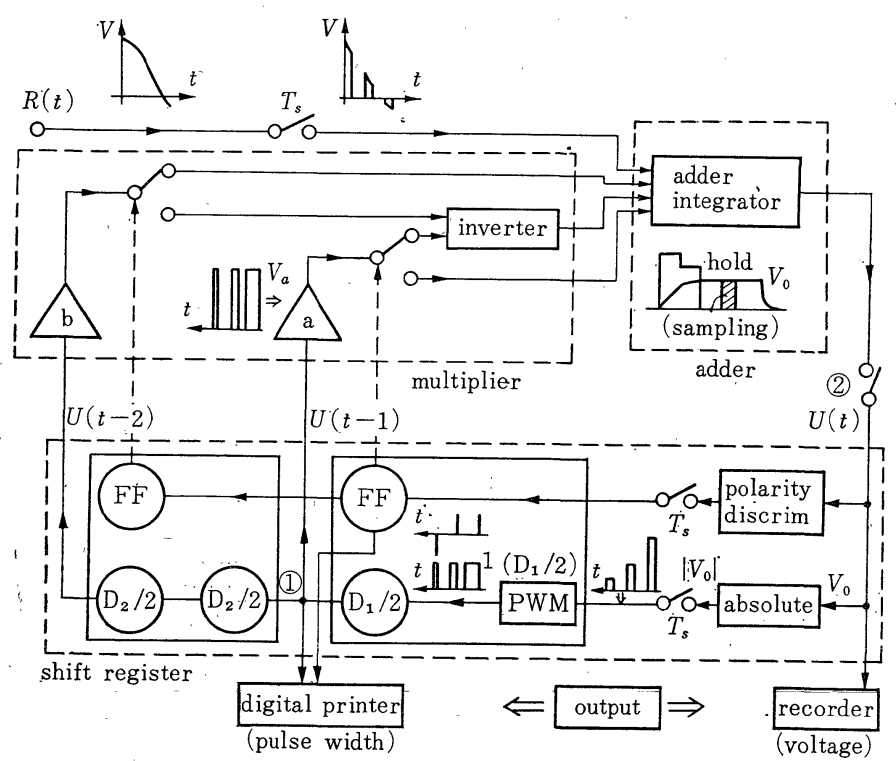

Fig. 15 Constitution of difference analyzer

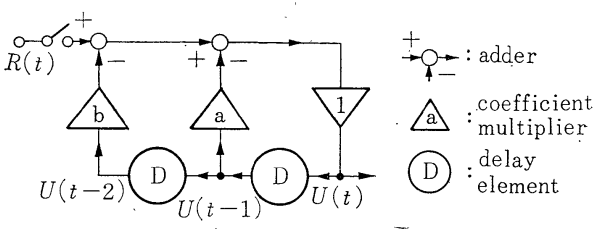

Fig. 14 Principle of difference analyzer

線で囲んである．以下シフトレジスタを除く各要素に ついて述べる.

Fig. 16 は係数 $a$ を乗算する場合を例にとって乗算 器の回路を示している.ここではシフトレジスタから の信号の絶対值であるパルス幅 $T_{1}$ と係数 $a$ に相当す る電压 $V_{a}$ との 1 象限乗算が行なわれ，信号は高さ $V_{a}$, 幅 $T_{1}$ のパルス面積 $(v o l t \times s)$ となる.このよ らに信号の極性と絶対值を分離したため, 乗算器が非 常に簡単になった。4 象限乗算は同図に示すように係 数 $a$ の符号によって手動切替スイッチを切り替えるこ とと, フリップフロップからの極性によって切り替る 自動切替スイッチにより行なわれる． $V_{a}$ の設定は加 算積分器, パルス幅変換器の変換係数をそれぞれ $k_{a}(=1 / C R), k_{p}$ とすると(15)式で決定される.

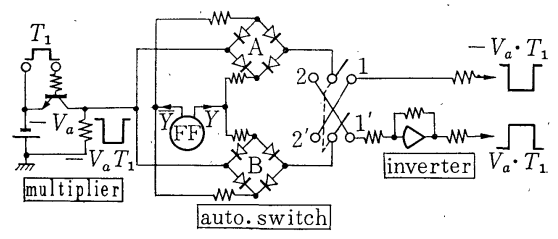

Fig. 16 Multiplier circuit

$$
V_{a}=a /\left(k_{a} \cdot k_{p}\right)
$$

加算器としては演算増幅器より加 算積分器を構成した. Fig. 17 に示 すよらにパルス面積で表わされる信 号を加算積分し，その電圧値 $V_{0}$ を ホールドして信号を電圧とする.こ のホールドされた電圧值 $V_{0}$ はサン プリングされ，その情報がシフトレ ジスタへ移った後, 次のサイクルの 入力信号に対して加算器として働く ために, リセット回路により零電位 にリセットされる.

出力としては解の現象を直観的に とらえられるように, 加算器の電圧 出力 $V_{0}$ をペンレコーダに描かせた。 さらに解を少しくおしく吟味する場 合のために, パルス幅出力と極性と をディジタルプリンタに記録した。 


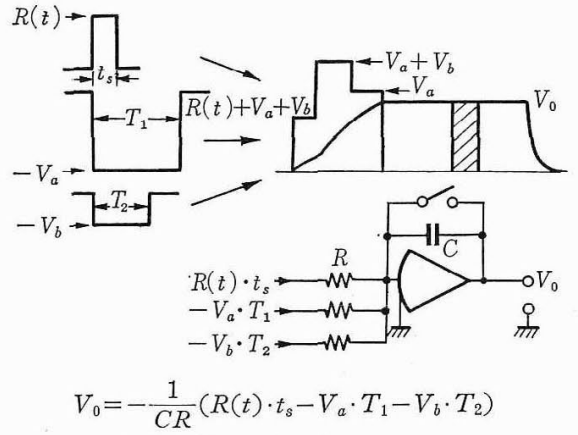

Fig. 17 Adder integrator

初期条件を入れるには Fig. 15 の (2)のスイッチを 切り, そこから初期值に相当与る電圧を入れ, 各遅延 素子に初期値を書き込む。

Fig. 18 亿実験結果の一例走示す. 電圧出力波形々 ディジタルプリンタのパルス幅出力の一部を示してあ る.（a )は差分方程式が相異なる 2 実根をもつ場合， （b）は虚根をもつ場合，（c）は非同次差分力程式の例 である。

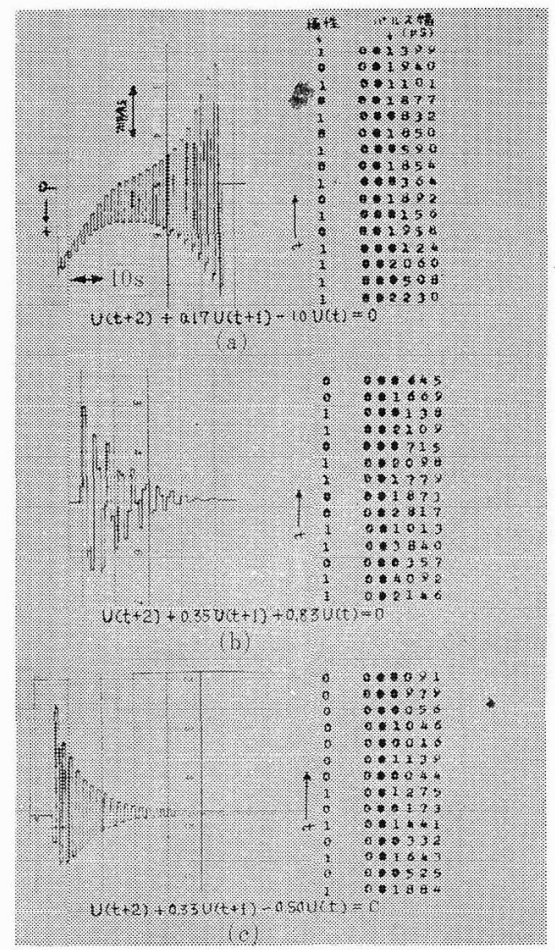

Fig. 18 Experimental results

これらの実験結果の值は計算值とほぼ一致して抒り, この差分解析器が差分方程式がどのような物理現象を 表わしているかを検討するための装置として適当なも
のであることがわかった，そしてこの方式は遅延線シ ンセサイザ（DLS）などの制御装置へも応用すること ができる、な挔この差分解析器の詳細に関しては今後 報告したい。

\section{5. まと め}

1 個の磁心より構成されたプリセット方式を用いた 㜊延素子が，従来のプッシュプル方式の問題点であっ た磁心の整合, 調整の困難さを改善するとともに, 容 易に $0.025 \%$ 程度の精度が得られることが確かめら れた。また，信号の極性と絶対值を分離してシフトす ることは，磁心の磁束量を有効に使用できるとともに， 応用のさいの周辺回路を簡単にすることがわかった. そしてこ狆らの特徽をいかして離散系の研究に有用な 差分解析器を構成できることを示した。

終わりに, 本研究を進めるにあたり故菊地正教授, 小西忠雄氏，樋口龍雄助教授に御指導いただきむした。 ここに愿く謝意を表わします。

\section{参考文 献}

1) 近藤・岩井・田丸：制御工学，3-2, p. 19 (1959)

2) Y. J. Kingma : Simulation, p. 65 (1968-2)

3）小西・囦地：白動制御，4-11， p. 410 (1965-11)

4) M. Sakao \& E. Ohno : IEEE, MAG-2-2 (1966-6)

5) 近藤・中西：第 10 回自動制御連合講演会, 208 (1967)

6) 小西・菊地：第 7 回自動制御連合满演会，203 (1964)

7）小西・大野・菊地：東北大学電通談話会記録，34$(1965-9)$

8) 菊地 ·三浦：炤和 41 電気四学会連大，251 (1966)

9)田所・穴山：第 9 问計測自動制御学会学術講演会, 313 (1970-8)

10）たとえば, D.L.Lafuze : Magnetic Amplifier Analysis p. 2 (1961) John Wiley \& Sons, Inc.

11) G. H. Barnes, et al. : Digital Applications of Magnetic Divices, p. 59 (1960) John Wiley \& Sons, Inc.

12）電子回路ハンドブック編集委員会編：電子回路ハンド ブック, p. 537 (1963)

13）たと党ば, Millman : Pulse Digital and Switching Waveforms, p. 343 (1965) McGraw-Hill.

14）回所・小西・菊地: 昭和 44 電気呬学会連大, 3340 (1969)

15) 田所：昭和 44 電気関係東北支部連大, $3 \mathrm{~B}-2$ (1969)

16）田所：計测自動制御東北支部第 31 回研究集会 (197011) 


\section{$\square$ 付 録一一記 号 表}

$E:$ 電圧パルスの高さ [V $], E_{\mathrm{in}}: \mathrm{PWM}$ の入力電 压 [V], $E_{w s}, E_{r s}, E_{p r s}$ : 書き込み, 読み出しおよび プリセット回路の電源電压 $[\mathrm{V}], \bar{E}_{w}, \bar{E}_{r}, \bar{E}_{p r}$ : 書き 込み, 読み出し拉よびプリセット時位心にかかる平、 均電圧 [V], $e_{w 0}, e_{r 0}$ : 書き込久特よび読み出し回路 の電圧電流特性を線形近似したときの不感帯電圧 [V], $\bar{I}_{w}, \bar{I}_{r}$ : 書き込久和よび読及出乙時の平均励磁 電流 $[\mathrm{A}], k_{a}:$ 加算器の電圧変換倸数 $[1 / \mathrm{s}], k_{f}:$ 。 ぞり磁束量の $T_{\mathrm{in}}$ に対する傾き $[\mathrm{Wb} / \mathrm{s}], k_{p}: \mathrm{PWM}$ のパルス幅变換係数 $[\mathrm{s} / \mathrm{V}], N:$ 巻回数 $N_{a d}:[\mathrm{T}]$, $N_{w}$ を変える利得調整用卷線, $N_{w}, N_{r}, N_{p r}, N_{0}$ : 書き 込み, 読み出し, プリセット物よび出力巻線の巻回数 [T], $N_{w b}, N_{r b}$ : PWM の書き込み拉よび読み出しの ベース回路の巻線, $r_{w}, r_{r}$ : 書き込みおよび読み出し回
路の電圧電流特性を線形近似したときの抵抗 [ $\Omega$ ], $R_{p r}: \bar{E}_{p r}$ を変える零点調整用抵抗 $[\Omega], T:$ パルス幅, $T_{s}$ : サンプリング周期 $[\mathrm{s}], T_{p}: \mathrm{PWM}$ の書き込みパ ルス幅 $[\mathrm{s}], T_{r}$ : 読及出しパル天幅 $[\mathrm{s}], T_{\mathrm{in}}$ : 入力 パルス幅 [s], $T_{\text {out }}, T_{\text {out }}{ }^{\prime}$ : 出力パルス幅拈よびプリ セット方式の補正される前の出力パルス幅 $[\mathrm{s}], T_{p r}$, $T_{c}$ : プリセット拉よび補正パルス幅 [s], $T_{r a}$ : 遅佂 回路の出力回路のトランジスタ, $V_{a}$ : 係数 $a$ 飞相当 する電圧 [V $], V_{\mathrm{in}}$ : 絶対値回路の入力電圧 [V $], V_{p}$ $:$ 極性出力電圧 $[\mathrm{V}], V_{0}$ : 加算器の出力電圧 $[\mathrm{V}]$, $\Phi_{T}$ : 磁束量 $[\mathrm{Wb}], \Phi_{m}$ : 飽和磁束量 $[\mathrm{Wb}], \Phi_{r \cdot s}$ : 残留磁束量 $[\mathrm{Wb}], \Phi_{w}, \Phi_{r}, \Phi_{p r}$ : 書き込み, 読み出 し拉よびプリセット磁束量 $[\mathrm{Wb}], \Phi_{f}, \Phi_{f \cdot p r}$ ：もど り磁束量呿よびプリ七ットによるるどり磁束量 [Wb]. 